Citation: Tok Turan, Z., Altun Yalçın, S. \& Çakır, Z. (2021). Use of entertaining educational materials in primary education (science teaching with games). International Journal of Scholars in Education, 4(1), 57-72. doi:10.52134/ueader.895511

\title{
Use of Entertaining Educational Materials in Primary Education (Science Teaching With Games)
}

\author{
Zerrin TOK TURAN*, Sema ALTUN YALÇIN ${ }^{* *}$, Zehra ÇAKIR*** $^{* * *}$
}

\begin{abstract}
The aim of the research is to examine the effect of game method made with entertaining educational materials on student's attitude towards science lesson and academic success. The sample consists of $30\left(6^{\text {th }}\right.$ grade) students, consisting of experimental and control groups. The research was applied for three weeks, 12 lesson hours in total. Mixed method was used in the study. Data collection tools "Attitude Scale towards Science", "Academic Achievement Test", "Student Interview Form and Researcher Observation Form" were used. The unit of "Conduction of Electricity" in the $6^{\text {th }}$ grade curriculum of primary education was chosen and the experimental group was taught with the method of play with entertaining educational materials, while the control group included a teaching method in accordance with the curriculum. As a result, a significant difference was found between the attitudes of both groups. Based on this result, it can be said that "Game Method with Entertaining Educational Materials" is more effective than teaching methods in accordance with the curriculum on students' attitudes towards science lesson. There was no difference in academic achievement test results. Interview results are; They stated that they did not have any difficulties while learning the subject, that they learned with fun, that they were happy in the lesson and that they were eagerly awaiting the next lesson. In the results of the observation form, it was seen that cooperation, responsibility, self-confidence and peer teaching among students increased.
\end{abstract}

Keywords: Academic success, Educational material, Science, Game, Attitude.

\section{İlköğretimde Eğlendirici Eğitsel Materyal Kullanımı (Oyunlarla Fen Öğretimi)}

Öz: Araştırma amacı, eğlenceli eğitsel materyallerle yapılan oyun yönteminin öğrencinin fen dersine karş1 tutumuna ve akademik başarısına etkisini incelemektir. Örneklem, deney ve kontrol gruplarından oluşan 30 (6. Sınıf) öğrenciden oluşturmaktadır. Araştırma üç hafta, toplamda 12 ders saati uygulanmıştır. Araştırmada karma yöntem kullanılmıştır. Veri toplama araçları "Fen’e Yönelik Tutum Ölçeği”, "Akademik Başarı Testi”, "Öğrenci Görüşme Formu ve Araştırmacı Gözlem Formu” kullanılmıştır. İlköğretim 6. sınıf müfredatında yer alan "Elektriğin İletimi” ünitesi seçilmiş ve deney grubuna eğlendirici eğitsel materyallerle oyun yöntemi ile öğretim yapılmış, kontrol grubunda ise müfredata uygun öğretim yöntemine yer verilmiştir. Sonuç, her iki grubun tutumları arasında anlamlı bir farklılık bulunmuştur. Bu sonuçtan yola çıkılarak, öğrencilerin fen bilimleri dersine yönelik tutumları üzerinde "Eğlendirici Eğitsel Materyallerle Oyun Yönteminin“ müfredata uygun öğretim yöntemlerine göre daha etkili olduğu söylenebilir. Akademik başarı testi sonuçlarında ise bir fark bulunmamıştır. Görüşme sonuçları ise öğrencilerin; konuyu öğrenirken zorluk çekmediklerini, eğlenerek öğrendiklerini, derste mutlu olduklarını ve bir sonraki ders için merakla beklediklerini belirtmişlerdir. Gözlem formu sonuçlarında ise öğrenciler arası işbirliği, sorumluluk, özgüven ve akran öğretiminin arttığı görülmüştür. Anahtar Kelimeler: Akademik başarı, Eğitsel materyal, Fen, Oyun, Tutum.

\footnotetext{
This article has been obtained from my master thesis (Zerrin TOK TURAN).

* Erzincan Binali Yıldırım University, Graduate School of Natural and Applied Sciences, Science Education Department, ORCID: (0000-0002-4300-8577), e-posta: zerrin.29@ hotmail.com

** Prof.Dr., Erzincan Binali Yıldırım University, Faculty of Education, Science Education Department, ORCID: (0000-0001-6349-2231), e-posta: saltun_11@ hotmail.com

*** Ph.D, Erzincan Binali Yıldırım University, Graduate School of Natural and Applied Sciences, Science Education Department, ORCID: (0000-0003-4585-8214), e-posta: zehracakir.29@ hotmail.com
} 


\section{Introduction}

Play is an entertaining activity that affects the physical, mental and emotional development areas of the child, has its own rules, and provides a pleasant time (Gülsoy \& Uçgun, 2013). It is a learning environment where the interests and needs of the child are seen in the most natural way. At the same time, cooperation is a social environment where feelings of responsibility can be developed (Gençer \& Karamustafaoğlu, 2014). Children spend most of their time playing. Therefore, the educational aspect of the game is focused on today. However, it is seen that the game, which is a natural learning tool for the child, is stuck between academic activities. Structured and restricted activities replace activities that children choose themselves, make their own rules, and play freely with fun (Fırat, 2013; Aksoy \& Dere Çiftçi, 2014). Play is the most natural learning tool for children to have fun, enjoy and rest (Koçyiğit et al., 2007; Gülsoy \& Uçgun, 2013). Therefore, games can be used as teaching materials in order to increase motivation, attention and learning towards the lesson (Akın \& Atıc1, 2015). With the games used in lesson teaching, the student takes an active part in the process, student-teacher relations increase and the lesson becomes efficient. It causes positive development in behaviors such as helping each other, establishing social relationships, thus increasing communication skills, selfconfidence, decision-making and helping each other (Genç, 2014). In addition, game is a learning method in which abstract concepts are concretized, provides permanent and meaningful learning and makes teaching enjoyable for children in primary school age and who are in the period of concrete operations (Gençer \& Karamustafaoğlu, 2014). Therefore, considering the age levels of students and their interest in games, educational games can be used to concretize and teach the subjects (Kaya \& Elgün, 2015). At this point, abstract lessons help to make permanent learning and consequently increase academic success by concretizing especially science lesson learning (Tok, 2016).

Educational play; it is all of the planned events that have the educational value that serves the student, willingly. By doing the student, it is a teaching tool that provides learning by living. Each game that serves training instruction has the educational value and is named as an educational game (Korkmaz, 2018). Inclusion of educational games in the learning process enables the increase in interest in the subject, improving the concepts of the concepts (Sar1, 2011). Helegly age of children in school, are in school, these years of children educational games make it easy to reach targeted behaviors and gains also ensures that the subject is repeated and reinforced (Yeşilkaya, 2013). Educational games are the feature of teaching the difference from other games. Teaching gains such as learning, reinforcement, evaluation and correction in the teaching process (Aslan, 2014). It should be used to increase students' active participation of students, to increase their active participation, will increase their motivation and attention, willingly, and the fun educational material to support the school and support this method in school, and the fun (Duran, 2014). At the same time, the course materials used in educational games direct the student to think and produce more (Güven, 2006). The aim of the games with educational materials is to increase the mental activities of the students and to ensure that it is to improve the acquisition of cognitive, affective, physical, social development areas through the game, as well as to improve the mental activities of the individual and to ensure learning while having fun to learn to learn the mental activities of the individual. In addition, the spirit is to achieve the mind and body health in place of responsibility (Aslan, 2014).

Today, the importance of the importance of scientific knowledge is increasing and the technology develops in parallel to the technology, it should be given to science and technology to take part in the world to be among the countries developing in the world (Hançer et al., 2003). Sciences: Thinking of knowledge of knowledge is the process of understanding the current knowledge and producing new information (Kapucu \& Çağlak, 2018). Science education is the training of the students' interest and needs, age levels, developmental levels, 
taking into account the environmental conditions, using the methods and techniques according to these features (Hançer, et al., 2003). It helps the child to produce solicitous problems in daily life, to establish a relationship between events and science between the events and the science, to recognize and to love the events, to recognize and to love them (Deniz, 2005). Lead to a positive attitude to science and technology (Hançer et al., 2003). The attitude is the trends, the tendencies to the events, situations, objects and people, positive or negative emotions (Üstüner, 2006). The aim of the education of science is to improve children's positive attitudes to the fene and nature, to give them to the questions they ask in these areas and to give up to the questions they ask for the questions and to keep up with the changing world (Bedir et al., 2009). However, the concepts of the concepts of science courses are abstract and complex, physics, chemistry, biology, and difficulties in the teaching and learning of the courses due to the incorporation of disciplines such as physics, chemistry, and biology and to the scientific concepts of the course and learning. All this leads to the formation of prejudice against the course and to be moved away from the course (Saracaloğlu \& Aldan Karademir, 2009). One of the units of such challenges is the İştireleri Transmission of Electricity in in the Primary 6th Grade Science program. There are too many abstract concepts in the unit.

For this reason, it becomes difficult for students to learn this subject (Kaya \& Elgün, 2015) and what is learned is forgotten in a short time, causing superficial learning and rote learning (Demir, 2012). This subject, which is taught with teaching methods suitable for the curriculum, does not attract the attention of the student enough and the lesson is boring for the child (Torun \& Duran, 2014). For learning to take place, prejudices in the individual must be eliminated, interest in the lesson must be increased, motivation and attention must be maximized (Bayram, 2015). In order for science teaching to be efficient and permanent, the methods and techniques to be used should be appropriate for the student levels and appeal to more sense organs (Uslu, 2011). Therefore, primary school students should be active in the learning process instead of learning by memorization in the course of the game period they are in. Teaching methods that are, questioned, learned by research, and that improve thinking skills and materials that will support and enrich them should be included (Bedir, Polat, \& Sakac1, 2009). Children between the ages of 6-14, which correspond to the primary school age, are play age children and learn best by doing and experiencing (Önen et al., 2012). According to Güneş (2012), the game method made with entertaining materials contributed to the students' attitudes towards the lesson, academic success, increased self-confidence, and research and inquiry skills in the science course. Learning becomes easier and more fun with games prepared with entertaining educational materials (Esgin et al., 2011). Hand skills and imaginations of children develop during the material and game preparation process. In addition, the child experiences the pleasure of producing something new (Ören \& Avc1, 2004). Abstract concepts are concretized with games prepared using materials prepared with simple and inexpensive materials that can be found easily from the environment, lessons are carried to daily life, interest and excitement towards the lesson increases. In the lessons taught in this way, effective, permanent and meaningful learning is provided by avoiding misconceptions (Yenice et al., 2019); Yildız et al., 2020). Thus, a successful result can be achieved in achieving the goals of the lesson.

The aim of this study is to reveal the effect of the use of play method with entertaining educational materials in the teaching of the "Electricity Conduction" unit in the 6th grade science course on students' attitudes towards science course and their academic success. In addition, this method is to determine the feelings and thoughts of children towards science lesson. 


\section{Method}

\section{Research Model}

The descriptive sequential pattern of the mixed method was used in the study. The mixed method is the collection, a research approach in which the researcher integrates the two data he collects both quantitative and qualitative data to understand research problems and draws conclusions by using the advantages of integrating these two data (Sözbilir, 2017). In this design, the aim is primarily to use quantitative methods and then to use qualitative methods to explain quantitative results in more depth (Creswell, 2002). To obtain quantitative data, a quasi-experimental design with "pretest-posttest control group" was created. A quasiexperimental model with pre-test and post-test control group was used to observe the two groups under the control of the researcher and to monitor the results (Karasar, 2007). In the study, the unit "Conduction of Electricity" was taught to the students of the control group (6-B class) using teaching methods in accordance with the curriculum. For the experimental group (6-A class) students; the lesson was taught with the game method made with entertaining educational materials. The symbolic representation of this model is as in Table 1 below.

Table 1

Symbolic Representation of the Research Pattern

\begin{tabular}{lccc}
\hline \multicolumn{1}{c}{ Groups } & Pretest & Process & Posttest \\
\hline Experimental Group & $\mathrm{T}_{1}, \mathrm{~T}_{2}$ & $\begin{array}{c}\text { Game Method with Entertaining } \\
\text { Educational Materials }\end{array}$ & $\mathrm{T}_{1}, \mathrm{~T}_{2}, \mathrm{~T}_{3}$ \\
\hline Control Group & $\mathrm{T}_{1}, \mathrm{~T}_{2}$ & $\begin{array}{c}\text { Teaching Methods in accordance } \\
\text { with the curriculum }\end{array}$ & $\mathrm{T}_{1}, \mathrm{~T}_{2}$ \\
\hline
\end{tabular}

T1 = "Electrical Unit Academic Achievement Test"

T2 = "Attitude Scale towards Science"

$\mathrm{T} 3$ = "Interview Form"

Teaching Methods Suitable for the Curriculum in the qualitative part of the study, semistructured interview technique was used to get students' opinions about the use of Game with Fun Educational Materials in the science lesson. The researcher determined eight questions, but after taking the opinions of the expert researchers in the reliability section, they were reduced to four questions. In addition, students' participation in the lesson, teacher-student relations, classroom interactions, difficulties and negativities experienced in the process, the situation of the environment and the highlights were observed by the researcher during and after the research.

\section{Universe and Sample}

The study was conducted with 6th grade students from a secondary school in the district of a city with a medium-sized population in the Eastern Black Sea Region. Two easily accessible groups were formed, the sample being an experimental group and a control group. It was paid attention to have a homogeneous structure in both groups in terms of important points such as the academic success of the classes that make up the experimental and control groups, and the same teaching teacher. In addition, attention was paid to ensure that variables such as the environmental conditions of the classes and the duration of the course are the same. Thus, class 6-A formed the experimental group and class 6-B formed the control group. The experimental group students (6-A) were taught during the "Electricity Transmission" unit (3 weeks $=3 \times 4=12$ lesson hours) by applying games with entertaining educational materials appropriate to the course outcomes, while the control group (6-B) students were taught in accordance with the National Education Curriculum. Curriculum-based methods were used. 
The number and gender of students in the experimental and control groups are presented in Table 2 below.

Table 2

Distribution of Experimental and Control Group Students by Gender

\begin{tabular}{lcc}
\hline Class Name & 6/A (Experimental Group) & 6/B (Control Group) \\
\hline Girl & 7 & 8 \\
\hline Male & 4 & 11 \\
\hline Total & 11 & 19 \\
\hline
\end{tabular}

\section{Data Collection Tools and Evaluation}

\section{Achievement test}

In the study, "Electricity Conduction" unit Academic Achievement Test, which was developed by the researchers, was used to measure the changes that may occur in the achievement of the students in the groups where the Game with Entertaining Educational Materials method was applied.

While developing the test in order to measure the success of the students in the unit of "Electricity Conduction", attention was paid to its applicability in existing secondary schools. For this reason, care was taken to adhere to the "Electricity Transmission" unit subjects specified in the science program prepared by the Ministry of National Education for the 6th grade secondary school, and the acquisitions in the unit were examined. For this purpose, before the test items are prepared, books, magazines, etc. The sources were analyzed and the questions were created by using the sample of questions in online tests, different test books, and acquisition screening tests. In the scoring of the Academic Achievement Test, which consists of 38 multiple-choice questions with four options;

- Correct answer ........... 1 Point

- Wrong answer .......... 0 Points

- A blank question ........... is rated as 0 points.

The test was evaluated over 38 points by giving 1 point to each correct answer in the test. For the content validity of the test, an indicator table was created in accordance with the subject gains and it was determined that the content validity of the questions in the test was sufficient by referring to expert opinions. Expert opinion was sought to determine whether the questions selected for the pilot application measure the behavior they aimed to measure, and the approved questions were put to the test. The prepared test was applied to $7^{\text {th }}$ grade students who learned the subject before. Based on the data obtained as a result of the application, the difficulty and discrimination index of all items in the test were calculated; the items deemed necessary were removed from the test and the test was finalized with 32 questions. Pilot application test results regarding the reliability calculation of the "Electricity Transmission" Unit Success Test are given in the Appendix.

Item discrimination power, item difficulty, and reliability coefficients were examined in data analysis. Item discrimination index shows to what extent an item distinguishes between an unknowing and an unknowing. The discrimination of items in a test varies between -1.00 and +1.00 . Questions with a discrimination index below .20 are items with low discrimination. Therefore, they must be excluded from the test. Questions with a discrimination of .30 and above are questions with excellent discrimination (Güler, 2011). According to the results obtained from the "Academic Achievement Test", the general discrimination degree of the 
achievement test applied was found to be .36. The correctness of the questions in an achievement test gives the test the difficulty. In an ideal achievement test, the average difficulty index of the questions should be around .50 (Güler, 2011). The average difficulty of the "Electricity Conduction Academic Achievement" test was calculated to be approximately .55. According to the results of the analysis made at the end of the application, the reliability coefficient KR-20 of the success test was found to be approximately .88 . The reliability coefficient calculated for a success test is .70 or higher, showing that the test is reliable. (Büyüköztürk 2004). Therefore, the result obtained from the success test prepared shows that the test is reliable and sufficient for use in research.

\section{Science Attitude Scale}

In the study, "Science Attitude Scale" with 20 items and 5-point Likert type prepared by Mertoğlu (2000) was used to determine the attitudes of the students in the groups where the game method made with entertaining educational materials was applied. The reliability of the scale was determined as $\mathrm{a}=.89$. Science attitude scale was applied to the students in the experimental and control groups before and after the application. By comparing the results of the application, it was aimed to determine whether there is a meaningful change between their attitudes towards the science course.

\section{Interview and Observation Form}

At the end of the study, questions were asked to the students to get their feelings and thoughts about the teaching process with the game method made with entertaining educational materials and to determine how this affects the lesson. Categories and codes were obtained by subjecting the data obtained here to content analysis. The observation technique that was not structured by the researcher was used during the science lesson, which was carried out by applying the game method made with educational materials. Throughout the game activities used in the course, students' participation in the lesson, teacher-student relations, interesting and different situations, classroom interactions, problems and negativities experienced during the process, the situation of the environment and points of interest were observed. In particular, it was tried to observe the interests and desires of the students in the science lesson, which was carried out by applying the game method made with entertaining educational materials. Observation records were made after the activity in order not to distract the class and not to disturb the teaching of the lesson.

\section{Data Analysis}

MANOVA, one of the statistical analyzes, was used in the analysis of quantitative data in this study, in which the mixed method was used. If there are more than one dependent variable and two independent (group) variables, two-way MANOVA is used to test whether there is any difference between groups (Can, 2016).

Content analysis method was used in the analysis of qualitative data (interview and observation data). Content analysis is a scientific approach that allows for objective and systematic examination of verbal, written and other materials (Sert et al., 2012).

\section{Application Steps}

First, experimental and control groups were formed in the research. Before the subject of "Conduction of Electricity" was taught, success and attitude scales were applied to the students in the experimental and control groups. 
In the experimental group, by using games made from entertaining educational materials in a constructivist approach, the subject of "Conduction of Electricity" was taught according to the time in the weekly course schedule. In other words, the research was carried out in 3 weeks, 12 course hours. In the study, education in accordance with the curriculum was carried out with the students in the control group. After the experimental procedures were completed, the same two scales were applied to the experimental and control groups as a posttest. In addition, at the end of the study, students 'opinions about the game method and the application process made with entertaining educational materials were taken in writing and it was tried to investigate the students' interest in the method. The data obtained were tried to be supported by the observation notes that the researcher kept about the behaviors and attitudes of the students before, during and after the lesson.

\section{Process (Selected Games for Electricity Transmission Unit and its achievements)}

Different games and materials were included in the research process in order to teach the key concepts, to make the subject grasp, to reinforce what has been learned, to evaluate the subject, to increase the interest and participation in the course. Games were prepared in accordance with the 6th grade "Electric Unit" achievements.

Games used in the research "Fish Catched to Electric Game (Classifies materials according to their state of conducting electricity using the electrical circuit he designed), Wheel of Fortune (Wheel of Fortune), Angry Science (Grizzly), Information Worm, Labyrinth, BilBoiler Drawer, Light Bulb, Bulb Mystery Book, Puzzle (Lists the precautions to be taken against electric shocks for the safety of himself and those around him), Match Card Receive Score (Expresses the difficulty of the items against the transmission of electrical energy as "resistance". He concludes that the resistance of a conductor varies depending on the length, cross section and type of the conductor), Electric Surprise Egg (He realizes that the bulb is also made up of a conductive wire and has a resistance. Classify materials according to their conductivity and insulating properties), Bowling (Electring) (Lists the precautions to be taken against electric shocks in terms of the safety of herself and those around her), Science Bala (Explain the purposes for which the electrical conductivity and insulating properties of materials are used with examples from daily life.), The Ring Game (He designs and makes a simple rheostat model to change the brightness of the light bulb in the circuit. Builds a simple electrical circuit and observes), Electro dart (Classify materials according to their conductivity and insulating state), Science This, Shorten The Cushion Duplicate Ball (He realizes by experimenting that the brightness of a light bulb in an electrical circuit can change by changing the length, cross section and type of the conductor in the circuit. It expresses the difficulty that materials show against the transmission of electrical energy as "resistance".), Science Rings (Predicts what the brightness of a light bulb in an electrical circuit depends on. He designs and sets up an experiment that will test his predictions about the brightness of the bulb. It expresses that the resistance of insulators is much greater than that of conductors.), games such as "Pop Balloon Find the Truth" were prepared and applied in line with the unit gains. Some of these games are games taken from various sources and generally used in other lessons. Some of them are games designed together with teachers and students. The most important feature of the games prepared is that they are created from cheap materials that can be easily obtained from the environment, and that the student is included in the process in the process of creating the game, increasing the fun and motivation, developing the imagination of hand skills, creating a new product and increasing the feelings of success and pleasure. Some of the games were prepared by the teacher before the lesson. The games were adapted to the learning outcomes of the lesson and applied. At the same time, it is aimed to increase the creativity of the students in the process of creating games together with the students. 
It was aimed to bring the games they play in daily life to the lesson, to make them a teaching tool and to carry the lesson to their outdoor games. The game names were also determined by the students. In the science applications lesson, the games played in other educational levels and lessons as well as the games played by the children in the past were shown on the smart board. In the later science applications lessons, the students were given time to design games and materials that they can use in science lessons. In this process, it was aimed for them to use their imagination and creativity by being free to choose the materials they used. The concepts of the 6th grade "Electric Conduction" unit that are taught with games are: "Conductor, Electrical Conductivity, Insulator, Electrical Insulation, Electric Shock, Circuit, Rheostat, Resistance, Electric Current, Electrical Resistance, Resistance Meter, Battery, Ohm, Electrical Resistance Depends Factors (Cross Section, Length, Type of Conductor)", Concepts to be given directly Filament, Tungsten (wolfram).

\section{Findings}

Findings and comments regarding the attitudes of the students towards the science lesson of the game method made with entertaining educational materials are as follows:

For the analysis to be applied to the quantitative data obtained, the correlation coefficients and significance levels between the dependent variables were calculated to find out whether there are significant statistical correlations between the dependent variables. As a result of this calculation, it was seen that there were statistically significant high correlations at the 0.01 level among the dependent variables. Accordingly, taking into account these statistical relationships between dependent variables, it was decided to conduct repeated measures, repeated measures MANOVA. After this stage, it was checked whether the data provided the MANOVA assumptions.

It was determined whether there are multivariate extreme values by calculating Mahalanobis distances. It was observed that no distance exceeded 16.2, which corresponds to 0.001 significance level. This means that there is no multivariate extreme value (deviation value). Another MANOVA assumption, Variance Covariance matrices, was found to be violated by the Box test (Box ' $\left.\mathrm{M}=37.449 ; \mathrm{f}=3.11 ; \mathrm{SD}_{1}=10 ; \mathrm{SD}_{2}=2586.5 ; \mathrm{p}=.001<.05\right)$. In addition, by looking at the results of the Box test, it was determined that the homogeneity assumption of the covariance matrices was not met. In the interpretation of the obtained results, Greenhouse-Geisser statistics were used due to the violation of the assumption of homogeneity of covariance matrices. If you have more than one dependent variable and two independent (group) variables and you are wondering whether there is any difference between groups, you can use two-way MANOVA (Şen, 2016). Levene's test, which is conducted to find the equality of variances of dependent variables, shows that the variances of the variables can be considered homogeneous. Below is the MANOVA results of the attitude.

Table 3

MANOVA Test Results for Each Level of the Experimental and Control Groups

\begin{tabular}{llllllll}
\hline $\begin{array}{l}\text { Dependent } \\
\text { Variable (Tests) }\end{array}$ & Grup & $\bar{X}$ & Ss & n & F & p & $\eta 2$ \\
\hline Success Pretest & $\begin{array}{l}\text { Experimental } \\
\text { group }\end{array}$ & 49.99 & 10.14 & 12 & & & \\
& $\begin{array}{l}\text { Control Group } \\
\text { Success Posttest }\end{array}$ & 36.45 & 11.69 & 18 & 3.827 & .060 & 0.120 \\
& $\begin{array}{l}\text { Experimental } \\
\text { group }\end{array}$ & 91.92 & 2.47 & 12 & & & \\
& Control Group & 64.92 & 17.46 & 18 & & & \\
\hline Attitude Pretest & Experimental & 66.25 & 7.65 & 12 & & & \\
\hline
\end{tabular}




\begin{tabular}{llllllll}
\hline & group & & & & & & \\
& $\begin{array}{l}\text { Control Group } \\
\text { Attitude Posttest }\end{array}$ & 66.61 & 6.12 & 18 & 66.92 & .000 & 0.705 \\
\cline { 2 - 5 } & $\begin{array}{l}\text { Experimental } \\
\text { group }\end{array}$ & 93.83 & 4.10 & 12 & & & \\
\hline & Control Group & 66,94 & 5,81 & 18 & & & \\
\hline
\end{tabular}

As seen in Table 3, when the Attitude dependent variable is examined, it is seen that there is a significant group interaction and the attitude towards science lesson creates a statistically significant difference $(f=66.92, p=.000, \eta 2=.705)$. While the pre-test average of the attitude dependent variable towards the science lesson was 66.25 in the experimental group, it was 66.94 in the post-test, and it increased from 66.61 to 66.94 in the control group. It is seen that the effect of the application on the attitude towards science variable was statistically significantly greater in the experimental group compared to the control group.

The answers given to the questions asked by the students, who were taught using entertaining educational material, in order to obtain their opinions about this method, are given below in tables after being subjected to content analysis.

Table 4

Experimental Group Students' Views on the Question "What do You Think About Teaching Science Lesson with Games"

\begin{tabular}{llllll}
\hline Mental & f & Affective & f & Teacher & f \\
\hline Permanent & 5 & Good & 5 & Advice & 1 \\
Recall & 2 & Excitement & 1 & Helper & 1 \\
Understanding & 3 & Fun & 2 & Labor & 1 \\
Learning & 1 & Useful for Me to & 1 & & \\
Understanding style & 1 & Difficulty & 1 & & \\
Topic repetition & 1 & Game & 1 & & \\
Game & 1 & & & & \\
\hline
\end{tabular}

Table 4 includes the answers of the students regarding the question and three categories were created. In the mental category: students think that this method is better learning, more permanent learning, easier remembering and understanding, learning by having fun, increasing their success, providing subject repetition, learning and learning style through play.

In the affective category; students in general; this learning method is a very good method, the students are excited for the lesson, they wait impatiently for the lesson time, have a lot of fun, do not have difficulty learning the subject, it is useful and learning with games is fun.

In the category of teacher: students advise other teachers to use this method in their lessons, they state that teachers put a lot of effort into using this method and it helps teachers with their teaching.

Table 5

Experimental Group Students' "Should Games be Used in Other Lessons? Why is That?" Opinions on the Question

\begin{tabular}{llllll}
\hline Cognitive & f & Affective & f & Other & f \\
\hline Helper & 1 & Fun & 4 & Age suitability & 1 \\
Permanent & 5 & Liking & 3 & Learning by practice & 1 \\
Recall & 1 & Claim & 1 & & \\
Easy answer & 1 & Interest & 1 & & \\
Learning & 6 & Not being bored & 2 & & \\
& & Happy & 1 & & \\
& & Wonder & 1 & & \\
\hline
\end{tabular}


Table 5 includes the answers of the students regarding the question and 3 categories were created. In the cognitive category; the reasons why students want them to be used in other lessons are the thoughts such as learning the subject, even better learning, retention in learning, easy remembering of what they have learned through games, and being able to answer questions easily.

In the affective category; making the lesson fun with games, loving the lesson, being eager to the lesson, not getting bored in the lesson, waking up curiosity about the lesson, making the students happy with games and increasing interest in learning life are the thoughts. In the other category; in general, students think that the use of games in lessons is appropriate for their age and that they learn in practice by becoming more active in the lessons.

Table 6

Experimental Group Students' "Did the Teaching of the Science Course with Games have any Benefits for You? If so, What are They? " Opinions on the Question

\begin{tabular}{llllll}
\hline Cognitive & f & Affective & f & Method & f \\
\hline Better Understanding & 1 & Interesting & 1 & Teaching Lessons with Games & 1 \\
Learning/ Understanding & 3 & Funny & 1 & Applied & 1 \\
Easy Answer & 2 & Beautiful & 2 & & \\
Benefit & 2 & Nice time & 2 & & \\
Permanent & 2 & Gratefulness & 1 & & \\
Not to mix & 3 & Claim & 1 & & \\
Again & 1 & Increased Interest & 2 & & \\
Success & 1 & & & & \\
Understanding-Not & 1 & & & & \\
Understanding & 1 & & & & \\
\hline
\end{tabular}

The answers of the students regarding the question are given in Table 6 and three categories have been created. In the cognitive category; the thoughts of the students were to understand the subject better, to be able to answer the questions easily, not to confuse the subjects, that teaching with games helps to repeat the subjects, increases their academic success and lecture grade, benefits themselves and the teacher sees who understands the subject or not.

In the affective category; the students have the thoughts that this method is interesting, the lessons become more fun, the lessons are beautiful with games, they have a good time in the lesson, their interest and desire increases, and they feel grateful to their teachers for the teaching of the lesson.

In the category of method; it includes the thoughts that students want their teachers to use the teaching method with games, so that they learn by applying the lesson and the subject.

Table 7

Experimental Group Students' "Did You Like Teaching Science with Games? If You Liked Why? " Opinions on the Question

\begin{tabular}{llllll}
\hline Cognitive & f & Affective & f & Method & f \\
\hline Academic success & 1 & Love & 9 & Play a game & 1 \\
Recall & 1 & Have fun & 7 & If only there were games in other lessons & 1 \\
Understanding & 2 & Like & 1 & Teaching Request & 1 \\
Game to Mind & 2 & Nice Time Not To Be & 2 & Learning by Game & 1 \\
More Lasting & 5 & Bored & 1 & & \\
Better Learning & 2 & Taste & 1 & & \\
\hline
\end{tabular}

In Table 7, students' answers regarding the question are given and three categories have been created. In the cognitive category: it was stated that the students' use of games in the lessons made what they learned more permanent. In addition, the students' thoughts were given 
that this method improves their academic achievements and lecture grades, and remembers the games they played and the subjects learned while answering the questions.

In the affective category: it was stated that the students liked the games played in the lesson, as a result, they liked the lesson, they were not bored, they had a pleasant time with fun and that they caused them to love their teachers more.

In the category of method; the students emphasized that they like to play games and that this method should be used in the teaching of other courses. They stated that they had fun with this method, their interest increased, they participated in the lesson, and therefore their teachers' desire to teach increased. In the code of learning with games, students stated that their learning is better with games, and at the same time, they both play and work.

Unstructured observation technique was used during the research in science lessons. Observations made were noted by the teacher at the end of each lesson. Obtained observation results are as follows.

It was observed that the students came to the next lesson voluntarily and the excitement, interest, participation in the activities and desire increased while the games were played. It was seen that the students wanted to take and play a role in every game. There was competition between the groups. It has been observed that cooperation and peer teaching among students in the same group have increased in order to win competitions with games. However, it was noticed that during the games in the form of a competition, the noise in the classroom increased and classroom management became difficult. It was observed that the whole class and especially the students with low academic achievement increased the willingness to answer the questions asked during this method.

It was observed that even indifferent students increased their motivation to the lesson they liked the games played, and they came to the lesson with ideas that would adapt the games they played in daily life to the lesson. At the end of the lesson, they asked what game they would play in the next lesson. It was observed that they came to the next lesson with curiosity. It was observed that they came to class in order to win games in the style of competition between groups and to play more games. It has been observed that they are eager to use the fun educational materials used in games. In other lessons taught by the same teacher, it was noticed that the students adopted and wanted to use this method.

It has been observed that extra course hours are needed in the process of producing and preparing games and materials, especially for students preparing for the exam, and they want to work for the exam and test solving.

In the process, it was observed that students displayed the behaviors of helping each other, giving ideas to each other, and producing by having fun. As a result, it has been realized that they compete with each other to create new products, which they see is not very difficult to produce something. It was noticed that the ideas about science applications course, science and project making changed positively. It has been observed that they establish a bridge between the science applications course and the science lesson and thus, they better grasp the place and importance of science and science lessons in our lives.

During the exhibition of the fun educational materials and games they produced at the TÜBITTAK science fair held at the school, it was observed that the students experienced the honor and pleasure of exhibiting the materials and games they produced and it was noticed that their sense of self-confidence increased. There were some problems in the first stage of the game. However, as the games were played, the game rules were adopted. They even learned to 
obey the rules and respect each other's rights at the end of the application. As a result of the observation made during the break, it was seen that the students approached the problems they encountered in daily life without fear and looked for solutions.

\section{Results and Discussion}

A significant difference was found in favor of the experimental group in the results of the attitude scale towards science applied to the experimental group in which the game method made with educational materials was applied and the control group in which the method in accordance with the curriculum was applied. In other words, it has been concluded that the game method made with entertaining educational materials is more effective than the methods suitable for the curriculum on the attitudes of the students towards the science course. In studies supporting the results, Demir (2012) and Akın \&Atıc1 (2015); They found that training with the game method caused a significant increase in science attitude scores. Korkmaz (2018) investigated student achievement and attitude on science teaching based on educational game development. As a result, it was seen that science teaching supported by developing educational games had a significant effect on the increase of students' attitude and academic achievement levels.

In the other quantitative result obtained from the findings of the study, it was observed that the post-test success scores of the experimental group and the control group increased according to the pre-test success scores. However, no statistically significant difference was found between the success scores of the experimental group in which the game method made with fun educational materials was applied and the control group where the methods suitable for the curriculum were applied. The reasons for the lack of significant difference between the posttest success scores of the groups may be as follows: Including activities that are suitable for the constructivist approach in both groups in the teaching process and that enable the student to be actively involved in the process may have caused the academic achievement scores of the learners to come out close. Gürol (2003), Balım et al. (2008), Akyol \& Fer (2010) 'research results have been found to support this idea. It may be due to the fact that the academic achievement test used to measure the success of students consists of multiple choice questions. Akyol \& Fer (2010) support this view in their study. Multiple choice questions increase luck success and the likelihood of cheating. It is also inadequate to measure high-level behaviors (partially analysis, evaluation, and especially the level of synthesis). The reasons mentioned above affect the reliable and accurate measurement of success by multiple choice questions. According to Gagnon \& Collay (2001), these tests are aimed at measuring what is not known rather than what is known. According to Y1ldiz (2010), because only the correct result is graded in such tests, reasons such as test anxiety, excitement, carelessness affect the test results. Therefore, in this study, learners may not be able to fully reflect what they have learned. For all these reasons, the academic achievement scores of the groups in the study may have been similar. Bektaş (2020) examined the effect of educational games on first-grade literacy skills in his study. As a result, it has been determined that educational games have a positive effect on student success.

Considering the results of the semi-structured interview technique conducted with the students in the qualitative dimension of the study, the majority of the students in the experimental group expressed positive thoughts about the game method with entertaining educational materials. They wanted all subjects and lessons to be treated with games. In line with the students' opinions, it was concluded that the method used in the study enabled repetition of the subject, helped remember, and enabled learning and enjoying with fun. They stated that learning was fun, they came to the lesson willingly, they were excited about the lesson, they became more curious about the lesson and they were impatiently waiting for the 
lesson time to make them happy with the game, they did not have difficulty learning the subject, they were excited about the lesson. Looking at the studies that support the qualitative results of the study: Kavşut et al. (2011), Önen et al. (2012), Demir (2012), Aral et al., (2012) stated that the use of the game method in the lesson enables learning by having fun, Yurt (2007), Saracaloğlu and Karademir (2009), Demir (2012) stated that it provides the pleasure of the lesson. In parallel with these results in the studies in the literature, Gülsoy and Arslan (2011) stated that it ensures not getting bored with the lesson: Coşkun et al. (2011) aroused curiosity about the lesson, Kavşut et al., (2011), Torun and Duran (2014) stated that games increase the excitement in the lesson and make students happy. These aspects of these studies are in line with the findings in our study mentioned above. In addition, they stated that they had fun because they were playing games, they were not bored in the lesson, they participated in the lesson more actively because it increased their interest in the lesson, they learned while having fun, helped them to repeat the topic, and what they learned was more permanent, they remembered what they learned more easily, and they were able to answer questions easily. Demir (2012), Gençer \& Karamustafaoğlu (2013), Kaya \& Elgün (2015) stated in their similar studies that the play method made with the materials increased the active participation of the student in the lesson. Kavşut et al. (2011) emphasized that it helps with topic repetition, while Gökbulut \& Soft (2014) emphasized that it helps to remember the subject. Tezel \& Aksoy (2020), eighth grade periodic system 'containing scientific story they investigated the effect of educational game activity. As a result of the study, it was determined that students had positive effects on their learning, attracted their attention and students liked these activities. Findings in these studies support the findings obtained from student opinions.

According to the researcher observation notes of the study, it was observed that cooperation, responsibility taking and peer teaching among students increased. It was observed that they came to the next lesson with curiosity. During the exhibition of the fun educational materials and games they produced at the TÜBİTAK science fair held at the school, it was observed that the students experienced the pride and pleasure of exhibiting the materials and games they produced, and it was noticed that their sense of self-confidence increased. Looking at the studies conducted in parallel with these results, similar results support it. Yildiz et al. (2020) investigated the effect of educational games and cooperative learning, and as a result, they found that the educational game method was more effective in improving students' social skills and motivation. Yenice et al. (2019) investigated the effects of educational games on fifth grade students' motivation to learn science. As a result, it was determined that the educational game application has a positive effect on science learning motivation. Erdal and Erdal (2003), Ayan \& Dündar (2009), Aral et al., (2012) stated that educational games increase the creativity of students, Bayram (2015), Karamustafaoğlu \& Kaya (2013), Akın \& Atıl (2015), Bayırtepe \& Tüzün (2007) stated that it increased pleasure, Coşkun et al. (2011) aroused curiosity, Karamustafaoğlu \& Gençer (2013) stated that they helped to cooperate and also teach obeying the rules. There is a similarity between the findings of Dağbaş1 (2007), Demir (2012), Kaya \& Elgün (2015) that it increases motivation in their studies and Torun and Duran (2014) makes it possible to love the lesson and the findings obtained from the observation results of our study. The findings of Yurt (2007), Dağbaşı (2007), Genç (2014) that caused an increase in students' interest in the course and the results obtained from the researcher's observation notes are similar.

In accordance with the constructivist education theory, the results of the attitude scale towards science obtained for the application of the 6th grade "Electric Conduction" unit with the entertaining educational material used in the teaching of the Game with Entertaining Educational Materials, the results of the observations and the students' opinions after the application can be listed as follows. As a result of the evaluation, it was seen that the concepts were learned and the gains were achieved. It was noticed that the behaviors of comprehending 
the logic of the subject and commenting instead of learning by memorization increased. A positive attitude towards the lesson was developed and participation in the lesson was increased.

The game method with entertaining educational materials is remarkable and entertaining, but also contributes to permanent and meaningful learning. Students have fun while learning, and learn while having fun. They willingly come to the lesson and actively participate in the teaching process. They want to do the activities over and over again. Thus, this method prevented them from getting bored in the teaching environment and enabled them to do activities willingly and fondly. Teaching with this method enabled the student to associate the lesson with daily life, to reinforce the lesson by carrying it into his daily life with games. The reason why the applied teaching method is intertwined with the game in accordance with the development level of the child and that concrete entertaining materials make the lesson more interesting are the reasons for increasing the interest and motivation of the student.

\section{References}

Akın, F. A. \& Atıcı, B. (2015). Oyun tabanlı öğrenme ortamlarının öğrenci başarısına ve görüşlerine etkisi [Effect of game-based learning environments on student success and opinions]. Turkish Journal of Educational Studies, 2(2), 75-102.

Akpınar, B. \& Turan, M. (2002). İlköğretim okullarında fen bilgisi eğitiminde materyal kullanımı [The use of materials in science education in primary schools]. V. National Education of Science ve Mathematic Congress.

Avcı, N. (2002). Çocuk ve oyuncak [Child and toy]. Abece Eğitim ve Ekin Dergisi, 2002, 12-14.

Ayan, S. \& Dündar, H. (2009). The importance of creativity and game in pre-school educational. Selçuk University Jorunal of Ahmet Keleşoğlu Faculty of Education, 28, 63-74.

Ayvacı, H. Ş. \& Yıldız, M. (2016). The evaluation of the effectiveness of the teaching process conducted through a laboratory material designed in accordance with 5E model: The refraction of light. Journal of Bayburt Education Faculty, 8(1), 1-20.

Baki, A. \& Gökçek, T. (2012). A general overview of mixed method researches. Electronic Journal of Social Sciences, 11(42), 1-2.

Bayram, B. (2015). The effect of mapped board games usage on the student success and recall in the Turkish Republic Revolution History and Kemalism lecture of $8^{\text {th }}$ grade. (Unpublished master's thesis). Adnan Menderes University, Institute of Social Science, Aydın.

Bedir, A., Polat, M. \& Sakac1, T. (2009). Performance application of the $7^{\text {th }}$ grade science and technology course: Portfolio. Celal Bayar University Journal of Science, 5(1), 45-58.

Bektaş, S. (2020). Investigation of the effects of educational games on first grade students' reading skills in teaching first reading and writing. (Unpublished master's thesis). Sakarya University, Institute of Education, Sakarya.

Can, A. (2016). SPSS ile bilimsel araştırma sürecinde nicel veri analizi [Quantitative data analysis in the scientific research process with SPSS] (6th ed.). Ankara: Pegem Academy.

Coşkun, H., Akarsu, B. \& Kariper, İ. A. (2012). The effects of educational games based on science stories on students' academic achievements in science and technology classroom. Ahi Evran University Journal of Kirşehir Education Faculty, 13(1), 93109.

Creswell, J.W. (2002). Educational research: Planning, conducting, and evaluating quantitative and qualitative approaches to research. Upper Sadle River, NJ: Merrill/Pearson Education. 
Çavuş, R., Kulak, B., Berk, H., \& Öztuna Kaplan, A. (2011). Fen ve Teknoloji öğretiminde oyun etkinlikleri ve günlük hayattaki oyunların derse uyarlanması [Game activities in science and technology teaching and adaptation of daily life games to the lesson]. IGEDER Summit of Science Teachers İstanbul.

Çeken, R. (2010). Fen ve teknoloji dersinde balonlu araba etkinliği [The Ballon car activity in science course]. Illkögretim Online, 9(2), 1-5.

Daşdemir, İ. \& Doymuş, K. (2012). The effect of using animation on primary science and technology course students' academic achivement, retention of knowledge and scientific process skills. Pegem Journal of Education and Teaching, 2(3), 33-42.

Demir, M. (2012). 7. Sınıf vücudumuzdaki sistemler ünitesinin oyun tabanlı öğrenme yaklaşımı ile işlenmesinin öğrencilerin akademik başarılarına ve fen teknoloji dersine karşı tutumlarına etkisi [The effect of teaching the $7^{\text {th }}$ grade body systems unit with a gamebased learning approach on students' academic achievement and attitudes towards science and technology lesson]. XVI. National Education Science Congress.

Esgin, E., Aksaya, H., Kırçalı, O., Direk, A. \& Kılıç, M. (2011). Determining the factors of interest to digital games and comparing them with properties of educational games. Gaziantep University Journal of Social Sciences, 10(4), 1291-1310.

Gagnon, G. W. \& Collay, M. (2001). Designing for learning: Six elements in constructivist classrooms. Corwin Press.

Genç, S. (2014). Importance of educational games in arts education. Bartın University Journal Of Faculty Of Education, 3(1), 380-392.

Gençer, S. \& Karamustafaoğlu, O. (2014). The views of students regarding teaching of "static electricity" with educational games. Journal of Inquiry Based Activities, 4(2), $72-87$.

Güler, T. \& Akman, B. (2006). 6-year-old children's views on science and scientists. Hacettepe University Journal of Education, 31(31), 55-66.

Gülsoy, T. \& Uçgun, D. (2013). Impact of educational games on development of $6^{\text {th }}$ grade student's vocabulary. Electronic Turkish Studies, 8(13), 943-952.

Gürdal, A. (1992). Importance of science in primary schools. Hacettepe University Journal of Education, 8(8), 185-188.

Gürol, A. \& Tezci, E. (2003). Constructivist instructional design and creativity. The Turkish Online Journal of Educational Technology, 2(1), 50-55.

Hançer, A. H., Şensoy, Ö. \& Yıldırım, H. İ. (2003). An evalation about the importance of contemporary science education at elemantary schools and how this kind of science teaching must be. Pamukkale University Journal of Education, 13(13), 80-88.

Demirel, Ö. (2007). Ögrretim ilke ve yöntemleri ögretme sanatı [The art of teaching, teaching principles and methods]. Ankara: Pegem Academy.

Kapucu, M. S., \& Çağlak, S. (2018). Pre-service science teachers' skills and experience on designing educational games: A case study. Adryaman University Journal of Social Sciences, 29, 536-573.

Karamustafaoğlu, O. \& Kaya, M. (2013). Teaching the subject of 'reflection and mirrors' with educational games: A case of reflective race. Journal of Inquiry Based Activities, 3(2), 41-49.

Karamustafaoğlu, S., Çostu, B. \& Ayas, A. (2005). Basit araç-gereçlerle periyodik cetvel öğretiminin etkililiği [Effectiveness of periodic table teaching with simple tools]. Journal of Turkish Science Education, 2(1), 19-31.

Karasar, N. (2007). Bilimsel araştırma yöntemi [Scientific research methods]. Ankara: Nobel Publishing.

Kavşut, G., Çavuş, R. \& Akpınarlı, N. (2011). Fen'in çemberi [Circle of science]. Eğitimde Değişim Hareketi Yeni Nesil Eğitim Konferans1 [Change Movement in Education and New Generation Education Congress], İstanbul University - Doğa College, İstanbul,

Kaya, S. \& Elgün, A., (2015). The influence of instructional games in science teaching on primary students' achievement. Kastamonu Education Journal, 23(1), 329-342. 
Koçyiğit, S., Tuğluk, M. N., \& Kök, M. (2007). Play as educational activity in the child's development process. Journal of Kazım Karabekir Education Faculty, 16, 324-342.

Korkmaz, S. (2018). Development and effectiveness of educational games inscience teaching as supplementary material on students'achievement and attitude towards science. (Unpublished master's thesis). Bartın University, Institute of Education Science, Bartın.

Mertoğlu, H. (2002). The Effect of active learning methods on learning how $8^{\text {th }}$ grade elementary school students learn nutrition concept. (Unpublished master's thesis). Marmara University, Institute of Education Science, İstanbul.

Önen, F., Demir, S. \& Şahin, F. (2012). Science teacher candidates' views about games and evaluating prepared games by them. Ahi Evran University Journal of Kirşehir Education Faculty, 13(3), 299-318.

Ören, F. \& Avc1, D. (2004). The effect of educational game teaching on academic achievement in science education course in subject of "solar system and planats". On dokuz Mayls University Jounal of Faculty of Education, 18, 67-76.

Saracaloğlu, A. S. \& Aldan Karademir, Ç. (2009). Eğlendirici eğitsel materyallerle oyun temelli fen ve teknoloji öğretiminin öğrenci başarısına etkisi [The effect of game-based science and technology teaching with entertaining educational materials on student success]. VIII. National Education of Primary Teachers Symposium, Osmangazi University, Eskişehir, 1098-1107.

Sert, G. \& Seferoğlu, S. S. (2012). Öğretmenlerin teknoloji kullanma durumlarını inceleyen araştırmalara bir bakış: Bir içerik analizi çalışması. Computers \& Education, 14, 46.

Sözbilir, M. (2017). Karma yöntem araştırmalarına giriş [Introduction of mixed methods research]. Ankara: Pegem Academy.

Tezel, Ö. \& Aksoy, K. (2020). Bilimsel öykü içeren eğitsel oyunla desteklenen fen bilimleri dersinin öğrencilerin periyodik sistem kavram öğrenmelerine etkisi [The effect of science lesson supported by educational game containing scientific story on students' periodic system concept learning On dokuz Mayls University Journal of Faculty of Education, 39(3), 192-209.

Torun, F. \& Duran, H. (2014). Effect of game method on success, permanence and attitude in children's rights education. Adryaman University Journal of Social Sciences, 16, 418448.

Uslu, S. (2011). The inspection of the effects of the worksheets to the students' academic in science and tecnology at the second degree. (Unpublished master's thesis). Adiyaman University, Adıyaman.

Yenice, N., Alpak Tunç, G. \& Yavaşoğlu, N. (2019). Eğitsel oyun uygulamasının 5. sınıf öğrencilerinin fen öğrenmeye yönelik motivasyonları üzerindeki etkisinin incelenmesi. E-Uluslararası Eğitim Araştırmaları Dergisi, 10(1,) 87-100. doi: 10.19160/ijer.369935

Yıldız, E., Ağgül, Ö., Çalıklar, Ş. \& Şimşek, Ü. (2020). The effect of educational games and cooperative learning on students' academic achievements, social skills and learning motivations. Journal of Social Sciences of Mus Alparslan University, 8(6), 1703 1716.

Y1ldırım, M. (2017). "There are or not" at science course with instructional games? Journal of Kazım Karabekir Education Faculty, 35, 14-30.

Yurt, E. (2007). Instruction of science through educational game technique and the placement and importance in new elementary education curriculum (An example of Muğla province, central district). (Unpublished master's thesis). Muğla University, Institute of Science, Muğla. 